\title{
Sprezzatura in Postmodern Perspective
}

\author{
S.Renuga Devi \\ Department of English, Bharathiar University, Coimbatore, Tamil Nadu, India
}

\begin{abstract}
Fashion in contemporary time is a prominent part of the art. In the status offashion, Postmodernism plays a huge role in the art world. In this research paper, the researcher deals with the idea of Sprezzatura in the modern world, and it plays a vital role in the concept of Sprezzatura in work The Book of the Courtier by Baldassare Castiglione in Postmodern perspective. In recent times people misunderstand the word Sprezzatura, and it changed people's inner thought and outer appearance through this concept.

Keywords: Naturalness, Elegant, Unsophisticated, Self Fashion, Baroque, Decorum, Ornamental, Architecture
\end{abstract}

\section{OPEN ACCESS}

Volume: 8

Issue: 2

Month: March

Year: 2020

P-ISSN: 2320-2645

E-ISSN: 2582-3531

Received: 15.01.2020

Accepted: 02.02.2020

Published: 01.03.2020

Citation:

Renuga Devi, S.

"Sprezzatura in

Postmodern Perspective."

Shanlax International

Journal of English, vol. 8, no. 2, 2020, pp. 32-36.

DOI:

https://doi.org/10.34293/

english.v8i2.2100

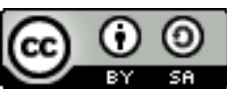

This work is licensed under a Creative

Commons Attribution-

ShareAlike 4.0

International License

\section{Introduction}

Sprezzatura's an Italian word that has been created by an author called Baldassare Castiglione in 1528 in a book called The Book of the Courtier. In this book, he lays down the rules by which the courtier should behave to receive the good graces of the kings and the princes. To practice in all things a certain sprezzatura or nonchalance, to conceal all art and make whatever is done or said appear to be without effort and almost without any thought about it. A prominent piece of advice that he gives people is to develop a sense of Sprezzatura. Sprezzatura makes people feel like the look, despite their hours of effort to come off as well dressed, is achieved effortlessly. The amount of time and energy put into looking good and presentable to others is guided and veiled in the form of non-calculated callousness, giving the impression that they woke up that fabulously to others. Sprezzatura is elegance by nature, not by effort. It's just the way he dressed. It's some a calculated nonchalant. If the man wants to appear nonchalant, although in the secrecy his room, he has been working a lot about how he would wear. But outside what he shows to others is a form of Casualness and nonchalant. Sprezzatura is elegance by nature, not by effort.

\section{Postmodernism and Fashion}

Post Modernism is often skeptical and allows multiple truths to exist at once. Postmodernist ideas such as Sprezzatura, when placed in the postmodern context, are changing in the effort to be new and exciting. The dictionary definition of fashion is a popular trend, especially in styles of dress and the manners of behavior. The world fashion is mainly associated with the habitual way a person dresses and expresses them. In the work Fashion as Communication, Malcolm Bernard states that modernity conceives the object in terms of production while Postmodernism conceives it in terms of consumption. This means that the focus is more on the consumers. Postmodernism celebrates the ability to actively fabricate truth and meaning with new interpretations and ways of seeing. 


\section{Sprezzatura in Modern Perspective}

Sprezzatura is the art of veiling the effort put into looking good and presentable. Italian nobleman and courtier Baldassare Castiglione was the first one to explain the background of the word Sprezzatura. In work, he says that a lot of people started to use this word as a gimmick, but in reality, Sprezzatura means to understand self fashion elegantly. For example, Stephen Greenblatt's Self-Fashioning 1980. Misunderstood the meaning of Sprezzatura, Most people have a vague idea that the way the people are dressing with a lot of flairs, exuberance, and flamboyance but that is the exact opposite of what Sprezzatura is. Sprezzatura is not about putting accessories and overdoing. It is about making people understand and believe how effortlessly sophisticated by nature one is. Some examples can be seen in the pictures of Priti Uomo and in certain websites who claim them to be a form of Sprezzatura who showed people with crazy socks, freaky hairstyles, tribal accessories, and the like.

\section{Understand about the Self Fashioning through Stephen Greenblatt's Self-Fashioning 1980}

Stephen Greenblatt, in his Renaissance self -fashioning from more to Shakespeare 1980, studies the sixteenth-century life and literature that spawned a new era of scholarly inquiry. Greenblatt inspect the structure of selfhood as evidenced in major literary figures of the English Renaissance. In this book, he examines the process known as the conditioning of one's self.

He defines self means as one's own identity or distinctive personality. Greenblatt recognized that this self is fashioned not only by external control mechanisms it also by various political, religious, and government institutions but also by a spectrum of inner forces such as personal beliefs, opinion, idols, things perceived as alien, strange or hostile. According to him, human history is the manifestation of closed-loop feedback between a man's self and man's cultural environment. This is fashioned by this very same self. In this context, one may look at literature and writers both as causes and victims of this sort of self-esteem fashioning. Greenblatt chooses six writers representing the English Renaissance to illustrate the working of such a feedback loop between the writers, and they are culturally envious. He extensively elaborate on a few texts authored by sir Thomas More's A Dialogue of Comfort Against Tribulations-1553 and Utopia-1516, William Tyndale's The obedience of a Christian man-1528, Sir Thomas Wyatt's Paraphrase of the penitential psalms of David -1542 and collected poems, Edmund Spencer's Faerie Queen-1590 and Christopher Marlowe's play Tamburlaine The Great 1590, Jew Of Malta-1633, Doctor Faustus-1604, Edward II-1594. The problem with Greenblatt's approach is his use of the term "self-fashioning. He limits the meaning of the verb fashion, owns identity and distinctive personality, but such a definition applies only to the underdeveloped part of man's consciousness, which is desires, egotism jealous, fear, pride, revenge, and a whole spectrum of crude attachment. Self fashion and sprezzatura it does not represent people's outer appearance only; it indicates people's inner thoughts also. This is the deceptive part of human consciousness, which is entropic in its very nature. There are other parts of consciousness that play a constructive role in the fashioning of man and his history. This subtler part is usually referred to as the inspired self.

Hans Holbein the Younger (1543) was a German painter and printmaker. He is considered one of the greatest portraits of the 16th century. His famous painting "The Ambassador" simplifying man's elegant thoughts and ideas as well as gestures. It is the process of awakening the more subtle part of consciousness, which is the driving force behind human history. Holbein's painting shows two wealthy noblemen standing at either side of a two - shelved table. The man on the left is in secular attire, while the man on the right is dressed in clerical clothes. On the upper shelf of the table are various instruments used for understanding the heavens and for measuring time. The lower shelf holds musical instruments and books. However, a large from that occupies the foreground of the painting attracts the viewer's attention. In this painting, he represents that Sufi poetry's famous quote, "Die before you Die." One has to die to earthly attractions and obsessions before one is capable of breaking through the operation of the deceiving self and experiencing the operation of the inspired self. Another example 
Leonardo da Vinci's masterpiece paintings such as The last supper, Mona Lisa and Vitruvian Man. These pictures indicate the artist's elegant thoughts and ideas.

Stephen Greenblatt used the term Self-Fashioning to represents the process of constructing own identity and public personal according to a set of socially acceptable standards. Self-Fashioning behavior was created for the Noblemen were instructed to dress in the finest clothing they could afford to be well versed and educated in painting art, culture, sports and other culturally determined noble exercise and to generally compose themselves in carefully intended manners. Characteristics of modern self-fashioning involve the use of feminine aspects of dress and conduct. One was to conduct the dress in a way that reflected people's position in society. One was not supposed to act in an affected manner but presents naturalness.

\section{Sprezzature in Art Culture Sprezzatura in Drama}

Commedia dell'arteis an Elizabethan play and European drama of 15 th century Italy. It is a street performance. Commedia dell'arte character represents everybody in society by improvised dialogue and the cast of colorful stock characters. These stock characters in drama are the best example of sprezzatura. The plays were fun and witty; it helped to define how comedy is a form that is still used today and can be seen in movies, television, and very popular in acting classes. The ability to be a comedic actor and engage the audience using on the spot witty dialogue is an amazing talent. Physical comedy is another element that started during the renaissance era and was established within plays to help keep the audience engaged. Physical comedy means the way the actors dressed up and when the actors use their bodies and other objects to bring comedic elements to the stage. Today you can see stand-up comedians who use physical comedy for reenacting a joke and allows the audience to visually be a part of the joke. It was also common for actors to use funny interpretations. This could include juggling or wrestling. Often the interpretation had nothing to do with the play itself but added excitement and spontaneous, elegant elements to the production.

The art and passion of theatre have provided entertainment for hundreds of years and is still relevant today. The elements of comedy as a form of entertainment will forever be popular, which allows Commedia dell' arte the opportunity to stay relevant in the theatre world. Masks with theatre plays are a great way to develop character, and Commedia masks, in particular, allow you to bring back the classic 16th-century art.

In drama, Sprezzatura is a certain nonchalant. It has to conceal all art and make whatever one does or says appear to be without effort and almost without any thought about it. In the cinema it is has been captured beautifully by directors. Sprezzatura is an effortless mastery of one's style; a studies carelessness that veils the work needed to create it. It is the very essence of compelling, stylish cinema and can be watched time after time. Sprezzatura cinema will never grow old; it's spirit will never be dimmed, it will forever be an inspiration to those who can see beauty.

\section{Sprezzatura in Writings}

At the beginning of writing carrier, people were followed by bold and formal language in their writing, such as Pindaric odes. It has three types of stanzas in each ode, based on choral dance positions such as strophe, anti-strophe, and epode. The prose writing should be splendid descriptions, long swelling speeches, magnificent epithets leading to abuse, and bombast. In poetry, the authors should follow the rhyme scheme, but in modern writing, people were started to write calm and colloquial language; there is no correct pattern to write a work. For example, classical writers they always followed ornamental and decorative writing style. This writing ordinary people can't understand easily. In the modern period, the writers don't follow any method to write; it should be Elegant and spontaneous. It leads to ordinary people who can also read.

In the poem, Sprezzatura is related to the sort of cool attitude. For example, the English writer Rudyard Kipling (1865-1936) he evokes in the opening of his poem "If"-means If you can keep your head when all about you if you can fake sincerity, you've got it made and to the oxymoronic expression act naturally. Another example John Milton (16041674)'s "Lycidas" it's a poem that ended with the 
word "New," which indicates every ending starts with new beginnings. What does sprezzatura have to do with rhetoric and composition? Some might say that it's the writer's ultimate goal. After struggling with a sentence, a paragraph, an essay revising and editing, again and again finding, at last, the right words and fashioning those words in precisely the right way. When that happens, after so much labor, the writing appears effortless. Good writers, like good athletes, make it look easy. That's what being cool is all about.

\section{Sprezzatura and Baroque Style}

Baroque is a style in art, architecture, music, and literature primarily in the European continent. In which the classical forms of the Renaissance are enhanced to achieve elaborate, grandiose, energetic, and highly dramatic effects. Captured the physical tensions of dynamic movement in painting and sculpture. As opposed to the tranquillity and mathematical perspective of the Renaissance artists. The word baroque derives from the Portuguese word "barroco" meaning "rough pearl." Baroque is different from Sprezzatura. Sprezzatura means elegant and natural; it has been simple and formal. In baroque, the people having so much ornamental sculpture and architecture, but in Some view, baroque also look elegant and natural. For example, Indian temples and Architecture such as TajMahal.

\section{Theorizing in Everyday Life}

Giovanni Agnelli was an Italian Industrialist and the richest man in modern Italian history. He was famous for a sense of Sprezzatura because he was very daring in the way he was dressing. For example, he loved to wear his watch above his cuffs, not under. It looks natural, but we never think him putting a lot of thought into that. He was spending a lot of time to pull off for those outfits, but at the same time, it was very nonchalant and elegant. This man was the best example of Sprezzatura. Nowadays, we can see even high-end restaurants and hotels using Sprezzatura to come off as classy and sophisticated without any effort. The same can be seen in the case of women who use the natural make up look to present themselves as effortlessly beautiful. Sprezzatura is, therefore, achieving elegance with effort but coming off as natural.

Without showing to others that people have been preparing themself. Through self-fashioning, people can maintain a better relationship with others, and people can have better quality interaction with others. That's what a man is looking for so damned. Sprezzatura is not a thing. It's we can't describe it. It shows the absence of a thing or more exactly is how the people hide their efforts and how the people cultivate within their boundaries. The art of appearing was nonchalant and nature, not by an effort. The best application and interfaces are so simple they appear to be without effort and are able to allow users to go about their business without any thought about it.

\section{References}

Appignanesi, R. and Garrett, C. Introducing Postmodernism: A Graphic Guide, Icon Book, London, 2003.

Blackburn, R. The Making of New World Slavery: From the Baroque to the Modern, 1492-1800, verso, New York, 2010.

Blunt, A. Baroque and Rococo: Architecture \& Decoration, Portland, 1988.

Branden, N. The Six Pillars of self-Esteem: The Definition Work on Self-esteem by the Teaching Pioneer in the Field, Bantam, 1995.

Burton, A. Performers's Guide to Music of the Baroque Period, The Associated Board of Royal school of Music, 2002.

Cabot, Aria Zan. "Eugenia Paulicelli, Writing Fashion in Early Modern Italy: From Sprezzatura to Satire." Forum Italicum, vol. 50, no. 3, 2016, pp. 1238-1240.

Carl, K. and Charles, V. Baroque Art, Parkstone Press, New York, 2009.

Castiglione, B. The Book of the Courtier, Penguin, UK, 2004.

Deleuze, G. Fold: Leibriz and the Baroque, University of Minnesota Press, 1992.

Galow, T. Writing Celebrity: Stein, Fitzgerald, and the Modern(ist) Art of Self-Fashioning (American Literature Reading on the 21st Century), Palgrave Macmillan, London, 2011. Greenblatt, S. Renaissance Self-Fashioning: From More to Shakespeare, University of Chicago Press, Illinois, 2005. 
Heller, W. Music in the Baroque, W.W. Norton, 2013.

Houser, A. The Social History of Art: Renaissance, Mannerism, Baroque, Routledge, 1990.

Kirwan, R. Scholarly Self-fashioning and Community in the Early Modern University, Routledge, 2013.

Havey, M. Self-Defense by Judo. Literary Licensing, 2011.

McClary, S. Modal Subjective: Self-Fashioning in the Italian Madrigal, University of California Press, 2004.

Neuman, R. Baroque and Rococo Art and Architecture, Pearson, 2012.

Norberg-Schulz, C. Baroque Architecture, Phaidon Press, 2003.
Paulicelli, E. Writing Fashion in Early Modern Italy: From Sprezzatura to Satire, Routledge, 2014.

Ray, Man. Self Portrait, Little, Brown and Company, 1963.

Richmond, C. and Smith, P. The Self-Fashioning of Disraeli 1818-1851, Cambridge University Press, 1999.

Roper, L. Witch Craze: Terror and Fantasy in Baroque Germany, Yale University Press, 2006.

Siblin, E. The Cello Suites: J.S. Bach, Pablo Casals, and the Search for a Baroque Masterpiece, House of Anansi Pr, 2009.

Viladesau, R. The Pathos of the Cross: The Passion of Christ in Theology And Arts the Baroque Era, Oxford University Press, UK, 2014.

\section{Author Details}

S.Renuga Devi, Department of English, Bharathiar University, Coimbatore, Tamil Nadu, India,

Email ID: renushri67@gmail.com 